\title{
Benzene, toluene and xylene measurements in the vicinity of petrol stations (Toulouse - France)
}

\author{
V. Simon, C. Borownjack \& C. Touya \\ Ecole Nationale Supérieure des Ingénieurs en Arts Chimiques et \\ Technologiques de Toulouse, \\ Institut National Polytechnique de Toulouse, France
}

\begin{abstract}
The monitoring of air quality on the urban agglomerations is a priority today and, within this framework, the benzene, toluene and xylene (BTX) concentrations are regularly measured. One of their principal atmospheric sources are the petrol stations: indeed, at the time of the filling of the fuel storage tanks or the vehicle tanks, there is vapor release of hydrocarbons, and more particularly of BTX which remains in the atmosphere. In order to study the impact of this source of emission on its vicinity, we choose to measure the concentrations in BTX around a petrol station using passive dosimeters of Radiello type in various points (above the pumps and in the district where the station is).

Dosimeters were installed from January 10 to January 30, 2002. The average atmospheric concentrations of benzene and BTX close to the pumps reached 28 and $293 \mu \mathrm{g} . \mathrm{m}^{-3}$ respectively whereas they are about 8 and $80 \mu \mathrm{g} \cdot \mathrm{m}^{-3}$ at the roadside. The use of a recovery device for VOC vapours should partially improve the air quality in the district.

Keywords: benzene, toluene, xylene, petrol station.
\end{abstract}

\section{Introduction}

Volatile organic compounds (VOCs) play an important role in atmospheric chemistry. This is especially true for substituted aromatic VOC such as toluene and xylenes which have a high photochemical ozone creation potential. They take part in photochemical reactions and are major sources of radicals which can 
oxidise $\mathrm{NO}$ to $\mathrm{NO}_{2}$ : the precursor of ozone (Finlayson-Pitts and Pitts [1]; Reis et al. [2]). Exposure to benzene has the potential for adverse health effects as it is genotoxic carcinogen (Snyder and Kalf [3]; Zhang et al. [4]; Lovern et al. [5]).

The regulation of major indicators for atmospheric pollution (ozone, nitrogen dioxide, sulphur dioxide) has been updated in recent years to include additional compounds like benzene.

In order to limit the benzene concentrations (highly carcinogenic) in the ambient air, the European Union fixed in its directive of December 14, 1999, to $5 \mu \mathrm{g} \cdot \mathrm{m}^{-3}$ the average atmospheric concentration limits to January 1, 2000. A guide value of $2 \mu \mathrm{g} . \mathrm{m}^{-3}$ is adopted in France as objective quality.

Amongst the principal atmospheric sources of BTX are the petrol stations: BTX average concentrations have been measured in the vicinity of a petrol station from January 10 to January 30, 2002.

\section{Methodology}

\subsection{BTX sampling and analysis}

BTX sampling can be carried out by various methods using Tedlar or Teflon bags, canisters or adsorbents respectively. The latter allow a sampling in either dynamic or passive mode. The advantage of a passive sampling mode is to provide a direct estimate of the average pollutant concentration corresponding to an acquisition period varying between few hours and few days (Brown [6]; Begerow et al. [7]; Kozdron-Zabiegala et al. [8]; Baldan et al. [9]; Zabiegala et al. [10]).

Radial diffusive samplers RADIELLO model were used (Figure 1). The diffusive surface is a synthesized polyethylene cylinder. The adsorbent was activated charcoal $(530 \mathrm{mg})$. The adsorbed compounds were analysed by gas chromatography (GC/FID, GC/MS) after a $\mathrm{CS}_{2}$ extraction (Cocheo et al. [11]). The gas chromatographic column was a DB1 (Alltech. $60 \mathrm{~m} .0 .32 \mathrm{~mm} .0 .25 \mu \mathrm{m}$ ). An internal standard 2-fluorotoluene was used for quantitative analysis (Simon et al. [12]).

The average concentration $\left(\mathrm{C}: \mu \mathrm{g} / \mathrm{m}^{3}\right)$ relative to the sampling period is given by the following expression:

$$
\mathrm{C}=\mathrm{m} \cdot 10^{6} /(\mathrm{Q} \cdot \mathrm{t})
$$

$\mathrm{m}(\mu \mathrm{g})$ is the mass collected over a period $\mathrm{t}$ (minutes), $\mathrm{Q}\left(\mathrm{cm}^{3} \cdot \mathrm{min}^{-1}\right)$ is the uptake rate (evaluated from laboratory experiments).

Blank values were determined on pre-conditioned tubes, which were carried with sample tubes during the sampling process. Sampling capacity and extraction efficiency of the tubes as well as stability of the compounds in the tubes were tested in earlier studies (Simon et al. [12]). Repeatability for benzene, toluene, xylenes was very good. The standard deviation of triplicate samples collected at same sites during both campaigns was below $10 \%$ for all compounds. 

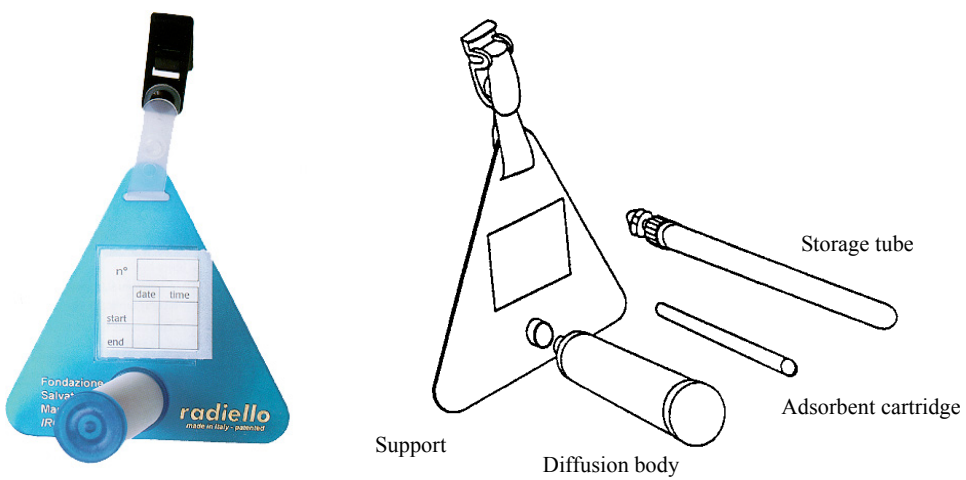

Figure 1: $\quad$ Radiello diffusive sampler.

\subsection{Study location}

We have selected 26 sites spread over an area of about $500 \mathrm{~m}^{2}$, in the vicinity of a petrol station (Figure 2). This one has not a recovery system of vapors above the pumps. Around $25000 \mathrm{~L}$ of gasoline were sold during the studied period. The area is crossed by a big traffic street called "Avenue de Rangueil".

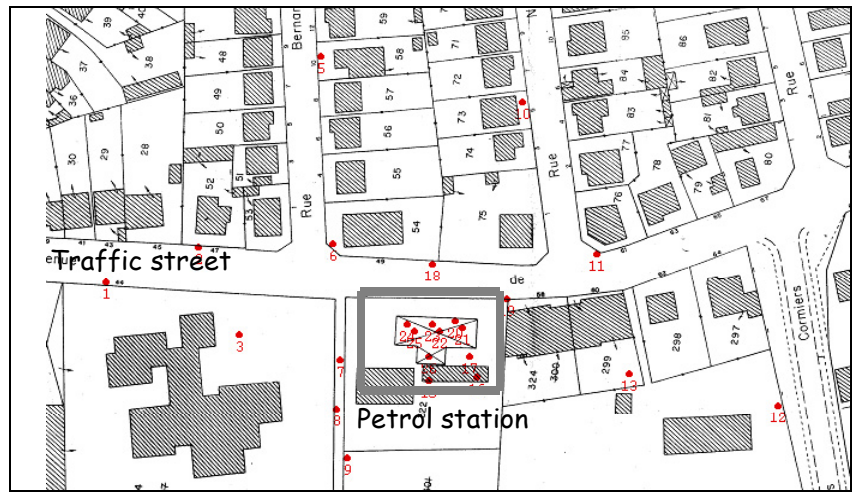

Figure 2: $\quad$ Studied area.

The number of selected sites is a good compromise between the cost of the study and the time available for collecting and analysing a representative data set. Sampling points were arranged over the petrol station. The dosimeters were thus generally installed on poles, at $2 \mathrm{~m}$ height, in such a way to avoid any wall screen effect. They were placed in polyethylene boxes in order to ensure protection against rain and solar radiation and to minimize disturbances due to the wind velocity. 


\subsection{Isoncentration plots}

Cartographic representations were made with the geostatistic computer program ISATIS which provides a set of statistical tools for incorporating the spatial coordinates of observations in data processing, allowing for description and modelling of spatial patterns, prediction at unsampled locations and assessment of the associated uncertainty. We only provide here representative plots corresponding to benzene and toluene.

\subsection{Meteorological conditions}

Main wind directions followed a northwest to southeast line: it is usual wind configuration in Toulouse. There were equivalent global speeds in both directions.

Mean air temperature was $9.1^{\circ} \mathrm{C}$ and mean relative humidity was $76.7 \%$.

\section{Results and discussion}

Atmospheric average concentration in benzene above pumps is $18 \mu \mathrm{g} . \mathrm{m}^{-3}$ and reaches a maximum value of $28 \mu \mathrm{g} \cdot \mathrm{m}^{-3}$ (Figure 3 and 4) whereas toluene and xylenes are characterized by average concentrations being respectively of the order of $105 \mu \mathrm{g} . \mathrm{m}^{-3}$ and $87 \mu \mathrm{g} . \mathrm{m}^{-3}$ (Table 1).

Table 1: $\quad$ Average concentration in BTX over the studied area.

\begin{tabular}{lccccc}
\hline $\begin{array}{c}\text { Average concentration } \\
\left(\mu \mathrm{g} . \mathrm{m}^{-3}\right)\end{array}$ & Benzene & Toluene & $\begin{array}{c}\text { Compounds } \\
\text { m,p-Xylenes }\end{array}$ & o-Xylene & All BTX \\
\hline Above the pumps & 18.3 & 105.1 & 66.4 & 20.8 & 87.2 \\
Around the road & 7.0 & 34.9 & 22.1 & 8.6 & 30.7 \\
In the lotissement & 4.6 & 21.6 & 14.0 & 4.6 & 18.6 \\
Dosimeter $\mathrm{n}^{\circ} 5$ & 4.3 & 20.8 & 14.1 & 4.7 & 18.8 \\
Dosimeter $^{\circ} 11$ & 7.7 & 37.3 & 27.6 & 8.8 & 36.4 \\
Dosimeter $^{\circ} 25$ & 28.1 & 147.8 & 89.2 & 27.7 & 116.9 \\
\hline
\end{tabular}

Along the main street, average benzene concentration is of $7 \mu \mathrm{g} . \mathrm{m}^{-3}$ while in the district it is of $4.6 \mu \mathrm{g} . \mathrm{m}^{-3}$. The concentrations are consequently very high if we refer to the standard value of $5 \mu \mathrm{g} . \mathrm{m}^{-3}$. The moderate wind speeds had only a small influence on the BTX distribution.

A recovery device of gasoline is thus indispensable to limit the exposure of the drivers during the completion of the reservoir. However, its introduction will contribute only weakly to the reduction of the atmospheric concentrations in BTX in the district: other measures must be taken to improve air quality in the district. 

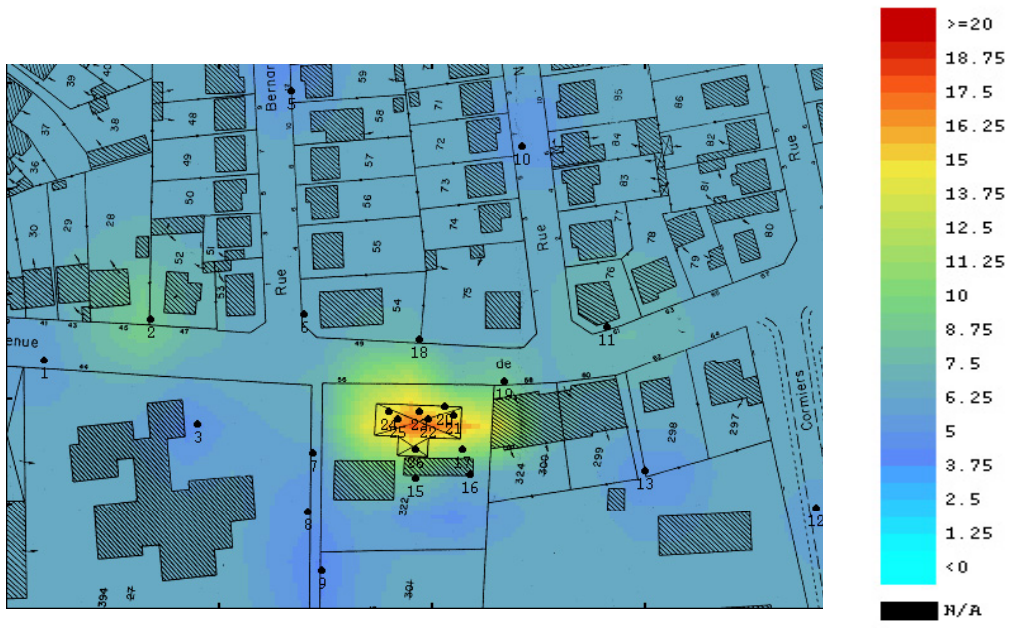

Figure 3: $\quad$ Isoconcentration plots for benzene $\left(\mu \mathrm{g} \cdot \mathrm{m}^{-3}\right)$.
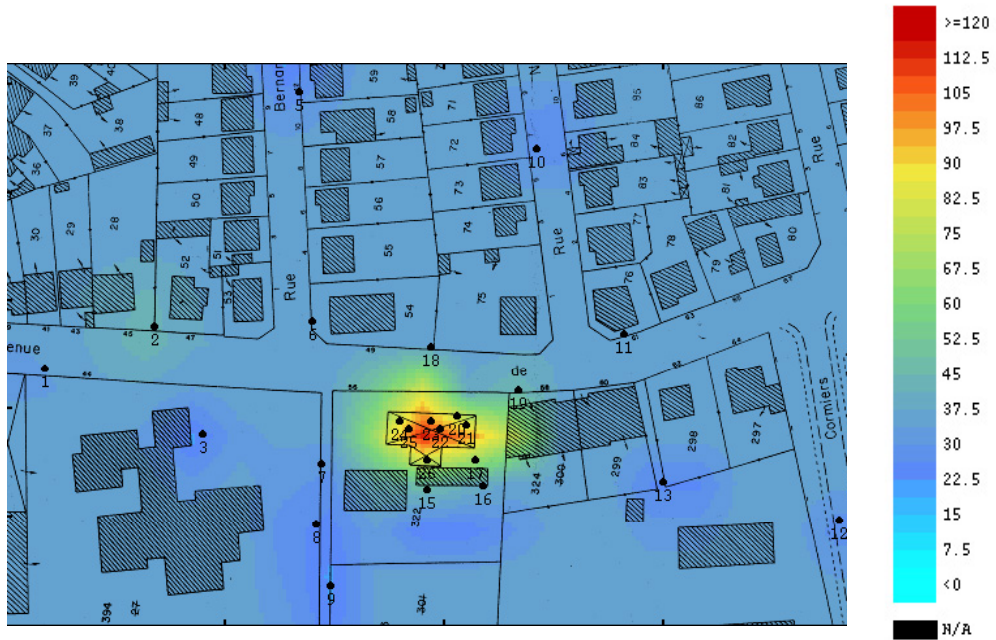

Figure 4: $\quad$ Isoconcentration plots for toluene $\left(\mu \mathrm{g} \cdot \mathrm{m}^{-3}\right)$.

\section{Acknowledgement}

We are grateful to ORAMIP for giving us some data necessary to the study. 


\section{References}

[1] Finlayson-Pitts, B.J. \& Pitts, J.N., Chemistry of the upper and lower atmosphere. Academic Press, 969 pp, 2000.

[2] Reis, S., Simpson, D., Friedrich, R., Jonson, J.E., Unger, S. \& Obermeier, A. Road traffic emissions-predictions of future contributions to regional ozone levels in Europe. Atmos. Environ. 34: 4701-4710, 2000.

[3] Snyder, R. \& Kalf, G.F. A perspective on benzene leukemogenesis. Crit. Rev. Toxicol. 24 (3), 177-209, 1994.

[4] Zhang, L., Rothman, N., Wang, Y., Hayes, R.B., Bechtold, W., Venkatesh, P., Yin, S., Dosimeci, M., Li, G., Lu, W. \& Smith, M.T. Interphase cytogenetics of workers exposed to benzene. Environ. Health Perspect. 104, 1325-1329, 1996.

[5] Lovern, M.R., Turner, M.J., Meyer, M., Kedderis, G.L., Bechtold, W.E. \& Schlosser, P.M. Identification of benzene oxide as a product of benzene metabolism by mice, rats and human liver microsomes. Carcinogenesis 18, 1695-1700, 1997.

[6] Brown R.H. The use of diffusive samplers for monitoring of ambient air. Pure Applied Chemistry 65: 1859-1874, 1993.

[7] Begerow, J., Jermann, E., Keles, T. et al. Passive sampling for volatile organic compounds in air at environmentally relevant concentration levels. Fresenius J. Anal. Chem. 351: 549-554, 1995.

[8] Kozdron-Zabiegala, B., Namiesnik, N. \& Przyjazny, A. Use of passive dosimeters for evaluation of the quality of indoor and outdoor air. Indoor Environ. 4: 189-203, 1995.

[9] Baldan, A., Pérez Ballesta, P., Cancelinha, J. \& De Saeger, E. Laboratory test for the validation of the Radiello diffusive sampler. Proceedings Venice 19-21 May 1999, 212, 1999.

[10] Zabiegala, B., Gorecki, T., Przyk, E. \& Namiesnik, J. Permeation passive sampling as a tool for the evaluation of indoor air quality. Atmos. Environ. 36: 2907-2916, 2002.

[11] Cocheo, V., Boaretto, C. \& Sacco, P. High uptake rate radial diffusive sampler suitable for both solvent and thermal desorption. AIHA Journal 57: 897-904, 1996.

[12] Simon, V., Baer, M., Torres, L., Olivier, S., Meybeck, M. \& Della Massa, J.P., The impact of reduction in the benzene limit value in gasoline on airborne benzene, toluene and xylenes levels, Science of the Total Environment 334-335, 177-183, 2004. 